Yayın Geliş Tarihi: 25.10.2020

Yayına Kabul Tarihi: 08.04.2021

Online Yayın Tarihi: 30.06.2021

http://dx.doi.org/10.16953/deusosbil.816079
Dokuz Eylül Üniversitesi

Sosyal Bilimler Enstitüsü Dergisi

Cilt: 23, Say1: 2, Y11: 2021, Sayfa: 569-585

ISSN: 1302-3284 E-ISSN: 1308-0911

Araştırma Makalesi

\title{
CHARLOTTE SMITH'S “BEACHY HEAD” AS A SPACE OF CONTRASTS
}

Şafak ALTUNSOY*

\begin{abstract}
This study concerns itself with the analysis of "Beachy Head" by Smith from the respect of prevalent contradicting forces such as Nature and culture or the historical time and the mythical past in the poem. The long narrative structure of the poem enables to present different voices reflecting the poet's ideological stance towards the contemporary issues in her time and exemplifies the excluding attitude of the ones representing the Neoclassical values. The study, in this regard, tries to clarify the functionality of the contrasts in the poem and their influence on the possible meanings of the text. The tension and the Sublime in the poem appear in the way that the speaker observes Nature and her surroundings in order to grasp the circulations in the natural world and her private sphere. Accordingly, the concepts of time and place lead to alternative spatial and temporal experiences for the poetic persona. Then, the text also turns into a space in which the persona confronts not only the bloody history of humanity but also the consoling past experiences she has lost by integrating into the cultural world. The study concludes that "Beachy Head" goes beyond its geographical and natural qualities by offering both a corporeal journey and visionary progress for the poetic persona through certain dichotomies constructed and deconstructed throughout the text.
\end{abstract}

Keywords: Charlotte Smith, “Beachy Head,” Culture, Romanticism, Contrast.

\section{BİR KARŞITLIKLAR ALANI OLARAK CHARLOTTE SMITH'İN "KIYI BAŞI" ŞIIIIII}

$\ddot{\mathrm{O}} z$

Bu çalışma Smith 'in "Beachy Head” (Klyı Başı) adlı şiirini tarihsel zaman, mitik zaman, Doğa, kültür gibi baskın karşıt güçler ekseninde incelemektedir. Şiirin uzun ve anlatıma dayalı yapısı, şairin kendi zamanının sorunları konusundaki ideolojik tavrını

Bu makale için önerilen kaynak gösterimi (APA 6. Sürüm):

Altunsoy, Ş. (2021). Charlotte Smith's "Beachy Head" as a space of contrasts. Dokuz Eylül Üniversitesi Sosyal Bilimler Enstitüsü Dergisi, 23 (2), 569-585.

*Arş.Gör., Dr., Selçuk Üniversitesi, Edebiyat Fakültesi, İngiliz Dili ve Edebiyatı Bölümü, ORCID: 0000-0002-5573-1121, shafakaltunsoy@gmail.com. 
göstermesine olanak sağlar ve neoklasik değerleri temsil edenlerin dışlayıcı tavrını da örnekler. Bu bakımdan çalışma, karşıtllkların metin içindeki görevini ve metnin muhtemel anlamları üzerindeki etkisini açılklamaya çalışır. Şiirdeki gerilim ve Yüce kavramı hem doğal dünyadaki hem de içsel yaşamdaki döngüleri anlamak maksadiyla şiir kişisinin doğayı ve çevresini gözlemlemesi şeklindedir. Buna ek olarak, zaman ve mekân kavramları da şiir kişisi için alternatif zamansal ve mekânsal deneyimlere yol açar. Bu durumda metin, kişinin kültürel olana dahil olup kaybettiği iç rahatlatıcı geçmiş deneyimlerinin yanı sıra insanlığın kanlı tarihiyle de yüzleşeceği bir alana dönüşür. Çalışma, metinde kurulan ve bu kurulanın yapısının söküldü̈gü farklı karşıtllklar vasitasıyla "Beachy Head" adl yerin hem bedensel hem de düsssel bir yolculuk olanağı sunarak doğal ve coğrafi niteliklerinin ötesine geçtiği sonucuna vartr.

Anahtar Kelimeler: Charlotte Smith, “Beachy Head (Klyı Başı),” Kültür, Romantik Akım, Karşıtllk.

\section{INTRODUCTION}

One of the women poets of the Romantic tradition, Charlotte Smith, poeticises the desire for a pure perception of human life through the observations of Nature. Unlike her male counterparts ${ }^{1}$, the poet does not try to reach a sense of the Sublime by putting Nature into a secondary place. On the contrary, Nature stands as a unique entity that has significance and power in its own right. In other words, it is not a means for a higher ideal or a means for glancing at the world of the Sublime but stays as a totality holding the primary position and thus, should be considered with its own merits. According to Sert, such perception of Nature is "another novelty that Smith brought to poetry" $(2018$, p. 22$)$ and stands as an essential element in questioning the poet's stance as 'Romantic' since the poet deliberately denies "transcendental aspect" $(2018$, p. 23$)$ in her poems. In this vein, even the abundance of flowers, birds and their names in Latin appearing in the footnotes or endnotes or the concern for grasping every change in Nature, every detail in the habitat of Beachy Head can demonstrate Smith's attempt to break with the conventional romantic perception of Nature. As Holt puts it, "Beachy Head, then, radically defies the confines of explicitly gendered feeling or reason, and thereby anticipates the altruism called for by contemporary ecocriticism" $(2014$, p. 1). However, the poet cannot entirely keep an objective tone throughout the poem with the presence of a culture

\footnotetext{
${ }^{1}$ Sert discusses that contrary to the representation of the Sublime feelings in the major male poets of Romanticism, Smith cannot "experience the sublime as the male Romantics did" and thus the Sublime does not lead to "a genuine semi-mystical awakening" (2018, p. 3). As Curran states, "For the three canonical male poets of the first generation of British Romanticism, however differently they construe its forces, nature is essentially an abstraction" (1994, p. 77). Although Sert's words, "she is not interested in going beyond the limits of that consciousness in the space of Wordsworthian egotistical sublime" (2018, p. 24) and "Charlotte Smith fails to use language in evocative and emotive fashion" (p. 31) affirm Curran's discussion about Smith's poetic stance, this study tries to argue that the attempt to 'go beyond' as an act of stoic existence through "Beachy Head" can suggest another dimension to Smith's way of Romanticism. For further gender-based discussions of Romanticism and Smith, please see Sert (2018).
} 
reminding her of the desire to separate from its chainlike temporality or heritage, and the impossibility of such a desire as the end of the poem underlines.

Therefore, in "Beachy Head," Smith reconsiders the poet's role as the one perceiving the others' sufferings, depicting her surroundings and narrating her own conflicts. She establishes her argument on the criticism of a culture artificially constructed and disconnected from the rhythm of Nature. A history full of evil deeds and mass destructions for "material gains through the abuse of power and exploitation" (Sert, 2018, p. 113) is also Smith's concern for demarcating the lines of the alleged civilised structure of humankind and the wild world. Thus, as Sert points outs, "the speaker begins to insert her criticism of man's brutality to each other and the history of violence that has terrorized the region over centuries" (2018, p. 88) through the landscape of Beachy Head. As being the main discussion in "Beachy Head," the circular temporality of Nature contrasts with the linearity of man's history that is subject to be forgotten. Furthermore, another binary signified in the poem is about the Newtonian perception of science asserting an absolute explanation or demystification. In opposition to the Neoclassical positivism, Smith offers the possibility of a different kind of existence by voicing the unvoiced thoughts and topography of the farmers, hermits, and mountain shepherds throughout the poem.

However, Smith not only describes Beachy Head's surroundings as a spectacular place but also maps the features of the ones surviving from a discourse closing people into specifically limited spaces and distancing them from their true 'nature' with the presence of so-called cosmopolitan concerns. Thus, the study analyses the poem for demonstrating the narrator's compassion ${ }^{2}$ towards certain figures such as the shepherds or the farmers appearing within another spatial border, the chalky cliffs of Beachy Head. Besides delineating the Romantic elements in the poem, this study tries to evaluate how Smith achieves a different perspective in her description of a natural spot by regarding the place not only as a starting point but an end on its own.

\section{CULTURE VS NATURE AS A ROMANTIC CONTRAST}

"Beachy Head" is a long poem in which the poetic persona or the poet starts with a description of the topography arousing specific sublime ${ }^{3}$ feelings or "a

\footnotetext{
${ }^{2}$ With "her sympathies to the marginal and the impoverished," "Smith believes that she is entitled to narrate the stories and advocate the rights of the disenfranchised" (Sert, 2018, p. 109)

${ }^{3}$ The study takes the Sublime as the way Edmund Burke describes the term in A Philosophical Enquiry into the Origin of Our Ideas of the Sublime and Beautiful (1757) in its general sense. According to Burke, "Whatever is fitted in any sort to excite the ideas of pain and danger; that is to say, whatever is in any sort terrible, or is conversant about terrible objects, or operates in a manner analogous to terror, is a source of the sublime; that is, it is productive of the strongest emotion which the mind is capable of feeling" $(1823$, p. 45). However, as Burke reiterates throughout his argument, such a feeling goes beyond a mere sense of fear by transferring horror into a more refined sense of pleasure originated from the seemingly negated fear. In this
} 
conventional sublimity" (Girten, 2013, p. 216). In her concern to describe, Charlotte Smith employs her notes aggressively with a diligent concern to be understood by the reader clearly. As Labbe points out, 'In 'Beachy Head,' Smith pursues a strategy that dispenses altogether with the hidden, using her footnotes to clarify and expand on the (hi)stories she poeticizes" (2011, p. 131). In a similar way, Tayebi states that "Yet all of the footnotes lead the reader toward the idea that there is an underlying order and classification to the overflowing abundance of natural phenomena in the world" $(2004$, p. 133). The text reflects not only the poetic persona narrating her experiences and memoirs of Beachy Head but also the poet's personal voice concentrating on the details of certain birds, places and historical heritage recreated with the view of Beachy Head and the countryside. Ruwe suggests that "as if this language were not specific to enough, Smith's endnote provides additional detail ... Throughout Beachy Head, the endnotes pile more details, history, and specific information onto the image she is glossing" (1999, p. 123). Then, the poet's notes do not provide only certain details about specific names but also, they turn into functional tools to sense the poet's ideological stance about history, biology or politics. As Labbe maintains, "the tone of the notes is factual and narrative-based, whereas the tone of the poem is colorful and image-based. In terms of the dramatized monologue, however, this goes beyond tone: we see that the speaker of the notes is aware of the poem, and reacts to its content, although the speaker of the poem seems oblivious to this competition, at least at first" $(2011$, p. 131). Sert discusses the function of footnotes by keeping a gender-based analysis that affirms Smith's "claim of authority as a poet" or "as spaces of authority" (p. 190) to consolidate "the scope of her knowledge" (2018, p. 182). Moreover, through the frequent appearance of the poet's own notes on the text, the poem leaves its long monologue style to a more interactive one from the reader's perspective.

Fletcher defines "Beachy Head" as a "topographical poem" (2001, p. 327), or it is "in the body of botanical poetry (with scientific notes)" (Roberts, 2019, p. 134). Even with such generic richness, "Beachy Head" reflects its depth not only as a typical example of British Romanticism but as the voice of a female Romantic poet's intricate mind (imagination). Thus, "Smith blends personal observation and historic detail, natural description and classical allegory" (Bernstein, 2007, p. 33).

\footnotetext{
respect, Smith's perception of "Beachy Head" affirms Burke's idea of the Sublime since the text alienates the actual place and the fear brought with it by turning it into an aesthetic source of pleasure through the poeticized sensory experiences. According to Sert, Burkean sublime is reflected merely on superficial level in the poem appearing as an imitation of the feeling poeticized by the male Romantic poets (2018, p. 75, p. 86). For further discussion, see Girten's comparison of Burke and Kant explaining the connection between the Sublime, fear and aesthetics (2013, pp. 216-217) and see Ruwe (1999, p. 123, pp. 128-129).

${ }^{4}$ Goodman also names Smith's poetry as "topographical poetry" (2014, p. 986). Accordingly, the idea of land in "Beachy Head" clarifies the tension between "local and global" (Goodman, 2014, p. 986).
} 
After seeing the high cliffs of Beachy Head, the speaker of the poem speculates on how it emerged in the south of Britain. Although she goes beyond the position of a mere observer, the first role attributed to her is to observe and appreciate as the following lines suggest,

\author{
On thy stupendous summit, rock sublime! \\ That o'er the channel rear'd, half way at sea \\ The mariner at early morning hails, \\ I would recline; while Fancy should go forth, \\ And represent the strange and awful hour \\ Of vast concussion; when the Omnipotent \\ Stretch'd forth his arm, ... (Smith, 2005, pp. 47-48)
}

The persona records each detail with auditory and visual images, which is a prevalent attitude of Smith in "Beachy Head." As Girten puts it, "the visual imagery of Charlotte Smith's poetry is striking for its microscopic attention to detail and its transporting effects" (2013, p. 215). Similarly, the persona diligently describes the sounds of the sailors crossing the channel and those of seagulls and flocks or the shepherd's dog. In other words, starting with the opening lines, the persona visualises the coexistence of different life forms within the centralised position of Beachy Head. In the "panoramic view" (Zimmerman, 1991, p. 75) of the cliff, the persona willingly accepts the role of a passive perceiver in the first lines, but throughout the poem, she combines the corporeal surroundings with the political criticisms on culture, which means her passive perceptions activate a fresh perspective for herself and the solitary figures' situatedness in the world. Thus, it can also demonstrate the poet's own ideological stance as a whole. As Garnai states, "Her final work, the posthumously published blank-verse poem Beachy Head (1807) further exhibits Smith's political awareness as it appears at the end of her life" (2009, p. 179). Moreover, similar to the perception of the Sublime by most of the male Romantics as mentioned before, Holt comments on the position of the persona in the beginning lines from another perspective with the words, "Smith does not maintain this 'privileged' view that suggests not only male poet over the general population but male poet over nature, but uses it immediately to establish that the view itself is one to be literally brought down to earth-both in attitude and subject matter" (2014, p. 2). As Sert points out, "Her fall from the mountaintop to the cave underneath is symbolic of her descent from the transcendental to the earthy" (2018, p.106). Additionally, the speaker's observing eye moving from above to the ground towards the end of the poem delineates a gradual confrontation with the inevitability of the cultural space.

Every being in the surroundings of the cliff shows a connection with the vast land in such lines as "And thy rough hollows echo to the voice/ Of the gray cloughs" (Smith, 2005, p. 48). Smith's note for "vast concussion" (p. 48) presents the assumption that ages ago, Britain was an integral part of continental Europe, but a 
natural force separated it (p. 48), which can imply the eternal reconstructive power of Nature on a larger scale than the situation of the isolated island.

"Beachy Head" underlines its biocentric concern through its depictions. Thus, the poem subverts the idea of anthropocentrism by depicting man's daily chores as in the cases of the approaching sailor and the shepherd driving his flock in the following lines, "The sloop, her angular canvas shifting still,/ Catches the light and variable airs/ That but a little crisp the summer sea" (Smith, 2005, p. 48) not as an interruption but as a part of the whole. Accordingly, the sailing boat does not disturb the tranquillity of the ocean at sunset time. On the contrary, it reflects the colours appearing in the sky and the ocean, as the "rough hollows" (Smith, 2005, p. 48) of Beachy Head mirror the creaks of various birds finding home and food on the cliff.

However, the persona historicises the culture of continuous attacks and conflicts specific to Britain in order to recreate the feeling of "sullen menace" (Smith, 2005, p. 50) aroused by means of the past experiences. As Labbe discusses, "The speaker-poet here reveals her slippery diction: Memory refers not to personal memory, the history of the poet, but to a kind of public memory" (2011, p. 132). Accordingly, the serenity of Nature and the sense of wholeness felt as a result are obstructed with the presence of historical residue. To illustrate, the persona of "Beachy Head" changes her perspective from the near surrounding to the distant fishing ships and the commercial ones, which triggers "recording Memory unfold/ her scroll voluminous" (p. 50). Thus, in her description of the "ship of commerce richly freighted" that "makes/ her slower progress, on her distant voyage,/ bound to the orient climates," (Smith, 2005, p. 49) the expansive colonialism of the Europeans (their trade "Defends the brows of Asia's countless casts"(p. 49)) and the issue of slavery ("which the slave,/ With perilous and breathless toil, tears off/ From the rough sea-rock, deep beneath the waves" (p. 49)) are collaged into man's failure to perceive Nature's real bestowing beyond 'ambition' exemplified with the trade of exotic goods such as spice and silk or precious stones since these only lead to man's suffering as follows,

These are the toys of Nature; and her sport Of little estimate in Reason's eye:

And they who reason, with abhorrence see Man, for such gaudes and baubles, violate The sacred freedom of his fellow man Erroneous estimate! As Heaven's pure air, Fresh as it blows on this aërial height, Or sound of seas upon the stony strand, Or inland, the gay harmony of birds, And winds that wander in the leafy woods; Are to the unadulterate taste more worth Than the elaborate harmony, brought out 
From fretted stop, or modulated airs

Of vocal science. ... (Smith, 2005, p. 49)

The persona criticises the positivist attitude that everything is explicable through intelligence. While she establishes her argument on the binaries of Nature (irrational) and Reason (rational), she also demonstrates the immense loss, the humane feelings, besides the holistic connection with Nature. In this regard, as Labbe states, "Nature provides not solace, but a constant reminder of what has been lost" (2011, p. 45). Therefore, the speaker disregards the precious stones by naming them as "toys of Nature," and "gaudes and baubles" (Smith, 2005, p. 49) when she compares them with the lost freedom. Thus, her humanitarian reaction suggests that cultured man is the primary threat to his species when he takes the material as a basis for his acts instead of empathy and emotions.

Moreover, another contrast appears in the "vocal science" (p. 49) and the natural sound. The tunes of the first one are limited, but Nature's sound is beyond any spatial restriction as it can be heard through "Heaven's pure air," (p. 49) the sea, the birds and the winds. The opposition between the artificial tunes of musicology and authenticity of Nature's sounds is extended into the comparison of the aesthetic difference between a crown embellished with gems and the stars as the following lines verbalise, "-So the brightest gems,/ Glancing resplendent on the regal crown,/ Or trembling in the high born beauty's ear,/ Are poor and paltry, to the lovely light/ Of the fair star" (Smith, 2005, p. 49)

The interconnectedness of separate elements in Nature to form the notion of oneness is visualised with various colours Nature grants in its "ethereal canopy" (p. 49). There, the persona experiences the sense of the Sublime as the lines suggest, "Thither aspiring Fancy fondly soars/ Wandering sublime thro' visionary vales" (p. 49). In those moments, the persona imagines an alternative world with royal images such as pavilions, trophies under "elysian bowers," (p. 49) which can indicate the doorway from the natural to the supernatural. However, this experience is momentary and only occurs in the times when the line between the world of the visible and the invisible ${ }^{5}$ is blurred as depicted in the change from the sunset to early evening, "then in paler light,/ Long lines of tenderer radiance, lingering yield/ To partial darkness" (Smith, 2005, p. 50). Thus, in "Beachy Head," by mythologising the sense of vision for the possibility of new perceptions, the idea of invisibility paradoxically contributes to a new way of imagination since it enables to go beyond the concern for factual details of Nature.

Nevertheless, the persona turns back to the detailed description of a “coaster" (p. 50). The speaker's attempt can signify the concern for reflecting the

\footnotetext{
${ }^{5}$ The discussion of invisibility in Smith's poetry can be based on the poet's concern with the microscopic details of Nature besides her neoclassical educational background or her interest in biology and botany (Ruwe, 1999; Fletcher, 2001; Labbe 2011; Girten 2013; Roberts, 2019).
} 
corporeal. The sailors disembarking the cargo from the ship to the dock seem to disturb the tranquillity of Beachy Head with their "loud clamours" (p. 50). However, Smith applies a Coleridgean polarity of thesis and antithesis in order to form a synthesis in the end. In Aids to Reflection, Coleridge suggests "Noetic Pentad" for the function and production of idea by defining thesis as "expressing being" (1847, p. 131), "the subjectively Real" or "position" (p. 132) and antithesis as "expressing act" (p. 131), "the objectively Real" or "opposition" (p. 132). After these two opposing forces, Coleridge offers synthesis that functions as "neutralisation" or "composition" (p. 132). Coleridge's pattern of 'mind' can be applicable to Smith's effort to give a detailed description of the natural world and her surroundings. In this respect, the coaster (thesis) reflects the sound of "busy hum" (synthesis) (p. 50) of the "wave-worn rocks" (antithesis) (p. 50). Then, seemingly different objects are unified in the presence of Nature. Additionally, the experience recounted as that in the moonlight, the small boat shines for a moment and "then lost in shadow" (p. 50) (again as Coleridge's "the subjectively Real" (p. 132)) demonstrates the persona's momentary experience on the visual level. Thus, the different objects with their own 'sounds' contribute to the serenity of the night and the fulfillment felt by the persona with her observations of the natural world.

The persona of "Beachy Head" is between the world of the present time and the past events that the cliff, she assumes, has seen. As Bode points out, "the subject of Beachy Head is not confined by any limitations of time or space" (2008, p. 63). Moreover, "Smith's speaker extends her line of sight beyond the contemporary political scene to document historical event" (Zimmerman, 1991, p. 76). Respectively, "Contemplation" leads her to have a connection with the "Memory" which "unfold[s] her scroll voluminous" (Smith, 2005, p. 50) by recounting the dark history of the island Britain with invasions and wars. History's roll of parchment reminds her of the Norman Conquest and the assaults of Scandinavian tribes. She projects the present situation of Britain for being threatened by France again, this time by Napoleon. As Goodman states, "during the French Revolutionary and Napoleonic wars, as Smith wrote most of her work, the watchful apprehension of what lay beyond the Channel coast was inseparable from the political questions and economic interests arising at the British border." $(2014$, p. 984). Therefore, the text conveys a melancholic or Romantic view of the past through the former invaders of the island and sustains a malevolent contemporariness full of conflicts and consistent threats. Moreover, the heroic mood of the wars disappears in the poet's time since no conqueror is singing "requiems for the slayers and slain" $(2005$, p. 51). As the following lines, "But let not modern Gallia [France] form from hence/ Presumptuous hopes, that ever thou again,/ Queen of the isles! shalt crouch to foreign arms" (p. 51) demonstrate, the persona wishes that Britain should not submit to the power of "the despot" with his "extorted sceptre" (pp. 51-52) as Italy and Spain did.

After the distressing influence of history, the narrator consoles herself with the depictions of the shepherds and the farmers. In the same lines, urban life is categorised under the head of History and the rural one in Nature. As the lines "From 
even the proudest roll by glory fill'd,/ How gladly the reflecting mind returns/ To simple scenes of peace and industry" (Smith, 2005, p. 52) can suggest, while history leads merely to destruction and sorrows remembered, the other one suggests a promising alternative. Two archetypes are poeticised in the shepherd figures, the one leaving his "more honest toil" (p. 52) of herding sheep for contraband trade and the other "hind" living in his "independent hut" (p. 52). The persona criticises the former figure for his ambition for earning more money than he needs. He puts his life into danger by coping with the snowstorms and the strong winds. Nevertheless, rather than his own fault, his misdeed is an inevitable result of his connection with the dominant discourse that is based on money and consumption as expressed in the lines, "Well it were for him,/ If no such commerce of destruction known,/ He were content with what the earth affords/ To human labour; even where she seems/ Reluctant most" (p. 52). Accordingly, contact with the culture and community spoils the harmonic connection with Nature. Thus, the persona cherishes the isolated location of the farmer by praising his loneliness, which gives the idea that being in the margin rather than in the centre and being savage instead of being cultured provides a nobler life than the bourgeoisie obtains with bright gems or blackmarketing. However, the farmer's life is not like "Arcady" (p. 53) appearing in "the poet's fabling dreams" (p. 53).

On the contrary, the farmer and his family have to endure the cold winter, the lack of opportunities, or the inconvenient conditions for farming (since the soil is "stony and cold and hostile to the plough" (p. 53)). "But he is free;/ The dread that follows on illegal acts/ He never feels; and his industrious mate/ Shares in his labour" (p. 53) and the coming of the spring restores their hope. His wife is not subject to the secondary position, and the meaning of gender roles makes no sense since they need to "patiently encounter" (p. 53) the hardships 6 in Nature.

The farmer depicted by the persona does not lose his connection with the labour-power and the products because he feels himself like an integrated part of the production process in a Marxian sense. In other words, since he is not isolated from his labour, he experiences not "sick satiety" (p. 53) but contentedness. As Tayebi points out, "Charlotte Smith demonstrates the detriment brought about by the abandoning of rural labor, such as shepherding and farming, for the smuggling that occurs along the coast of England. Although more profitable for the worker, smuggling brings about a cost not only of human life but of morality and consequently the alienation of the individual" $(2004$, p. 135). In this respect, the farmer feels a sense of fullness when compared to the lack the ones in luxurious life

\footnotetext{
${ }^{6}$ According to Tayebi, Smith does not romanticise the struggles of the farmers as if it is a stoic acceptance (2004, p. 136). However, although the poet keeps an objective attitude towards her subject matter throughout the poem, when the comparisons between the ones in the space of Nature and the ones outside of its circle, it can be said that the poet regards the farmer's life is more meaningful and closer to the sense of wholeness than the ones in favourable conditions.
} 
experience as stated in "the child of Luxury/ enjoying nothing, flies from place to place/ In chase of pleasure that eludes his grasp" (Smith, 2004, p. 54).

\author{
Ah! who is happy? Happiness! a word \\ That like false fire, from marsh effluvia born, \\ Misleads the wanderer, destin'd to contend \\ In the world's wilderness, with want or woe- \\ Yet they are happy, who have never ask'd \\ What good or evil means. The boy \\ That on the river's margin gaily plays, \\ Has heard that Death is there.-He knows not Death, \\ And therefore fears it not; and venturing in \\ He gains a bullrush, or a minnow-then, \\ At certain peril, for a worthless prize, ... (Smith, 2005, p. 54)
}

The narrator of "Beachy Head" points to the difference between Nature and culture from the respect of language and morality in the above lines. According to her, defining the word happiness cannot contribute to the farmer's happiness because meaning is formulated and manipulated in accordance with the dominant discourse. In the farmer's case, he cannot be called the happy one because of the poor life he maintains when appreciated from the centre of the wealthy ones. Moreover, it would intensify a desperate feeling for the farmer when the meaning of the word 'happiness' constructed through the urban values is imposed on him. Asking "what good and evil means" (Smith, 2005, p. 54) also registers the individual to the dominant ideology and moralises his behaviours. When the farmers and their families never ask such questions, they keep themselves away from the artificial pressures of society, which grants them a sense of freedom.

Furthermore, in "Beachy Head," Smith subverts not only the concept of real wealth but also the perception of death through the land, Beachy Head. As Fletcher points out, "Beachy also meant death. It has been a notorious place for suicides since at least the seventh century, when St Wilfrid found the locals jumping off after a three-year drought" (2001, p. 330). However, Smith changes that factual detail into a rumour from the child's perspective. Thus, the line "Has heard that Death is there.He knows not Death" $(2005$, p. 54) can delineate how the poem's speaker narrates a different reaction towards death anxiety. To be more precise, his son's knowing nothing about the notion of death can transform the word into an empty signifier that has no referent in the actual surroundings of the boy. In this regard, it cannot produce a definite meaning, and the son does not feel the destructiveness of death and temporality while playing near the banks of the river or climbing a tree.

... Early it came,

And childhood scarcely passed, I was condemned,

A guiltless exile, silently to sigh,

While Memory, with faithful pencil, drew

The contrast; and regretting, I compar'd 
With the polluted smoky atmosphere

And dark and stifling streets, the southern hills

That to the setting Sun, their graceful heads

Rearing, o'erlook the frith, ... (Smith, 2005, p. 54)

The happy state of the boy and "the village girl" with her "bonnet newly purchased" (p. 54) reminds the persona of her own childhood. She changes her perspective from the outer observations into the inner feeling of a personal loss. Thus, throughout the poem, she not only voices the figures seen from the cliff of Beachy Head but also her own emotions. As Paterson discusses, "in the wider context of the place Beachy Head as well as the poem, they become part of a new narrative of personal history" $(2019$, p. 24). Therefore, the persona concedes that her 'I' undertakes a journey from the natural space to the cultural one.

Moreover, the sense of wholeness she feels in her childhood period and "the upland solitudes" or "mountain air" (Smith, 2005, 54) leave their place to the dirty streets and a suffocating air in her adulthood stage. In other words, as Patterson exemplifies in Smith's other sonnets, "a happy childhood playfully engaged with the natural world becomes a life of sorrow; memories of the past only serve to heighten that sorrow through their painful 'contrast"' $(2019$, p. 24). However, although the speaker knows that she cannot turn back to those years of childhood, she finds solace in the reimagined topography and the nostalgia of her memories.

As the following lines, "Haunts of my youth!/ Scenes of fond day dreams, I behold ye yet!" (Smith, 2005, p. 55) denote, the poetic persona develops a defence mechanism for the melancholy ${ }^{7}$ of being displaced. In this respect, her focusing on the descriptions of "village church" with "those lowly roofs of thatch are half concealed" by "the rude arms of trees" (p. 55) can signify her return to the patriarchal system from the imaginary one. Still, the appearance of boughs promises the possibility of a connection with childhood emotions since "With fond regret I recollect e'en now/ In Spring and Summer, what delight I felt/ Among these cottage gardens" (Smith, 2005, p. 56). In the lines the persona retelling her past experience of faith as "an early worshipper at Nature's Shrine" (p. 56), she alludes to her current state as if it is a conversion from the natural religion to the systematised one. However, her yearning for the previous faith is only satisfied in the visions as stated in "Ah! hills so early loved! in fancy still/ I breathe your pure keen air" (p. 56).

\footnotetext{
${ }^{7}$ According to Bernstein, "Smith's poetry is a record of deep melancholy, frequently dwelling on the injustice and ceaseless worry of life" (2007, p. 30). Similarly, Cognevich states that "largely read as lyrics of sensibility, Smith's sonnets are characterized by melancholy as they attempt to express a complicated grief" (2020, p. 2). However, as Pratt discusses in Smith's sonnets, the poet's perception of melancholy goes beyond the reductionist attitude of the male ones (2001, p. $575)$.
} 
"Science' proudest boast" (Smith, 2005, p. 57) delineates the failure of scientism ${ }^{8}$ dominant in the eighteenth century. Thus, "Nature cannot be easily read, even through science" (Tayebi, 2004, p. 141). To illustrate, the speaker recounts a scientist investigating "these fossil forms" (Smith, 2005, p. 57) and ends up in "vague theories" (p. 57). In other words, according to the persona, although some attempt to explain a phenomenon scientifically, they only form their opinions from incomplete theorems. As the lines "While to his daily task the peasant goes,/ Unheeding such inquiry; with no care/ But that the kindly change of sun and shower,/ Fit for his toil the earth he cultivates" (p. 57) suggest, the peasant grasps the actuality in his simple daily deeds and is not away from his immediate surroundings. As Sert points out, the lines reflect a Wordsworthian praise towards "the peasant (the nonscientific mind of the underprivileged who knows other valuable things than science)" (2018, p. 94). For instance, his observations on the changing movements of the sun contribute to his struggle with the hard soil. The persona also compares the reactions of the peasants and "some lonely antiquary" (p. 57) towards the remains of "a huge unwieldy Elephant" (p. 57). As the lines "The wondering hinds, on those enormous bones/ Gaz'd; and in giants dwelling on the hills/ Believed and marvell'd" (p. 58) clarify, the peasants mysticise a historical object against the demystification of the scientist who explains the story of the elephant coming from Africa during the Roman invasion. "Yet Smith is concerned throughout her poem to allow multiple narratives to exist at once, not to deny them, and her second narrative of fossil origin accomplishes this" (Paterson, 2019, p. 29).

Furthermore, the circular time of Nature sweeps the tracks of history. The persona extends the fossil image with the "Ambition" (p. 58) of man to be immortal, but only "Earth" (p. 58) keeps its infinite essence. For instance, "The pirate Dane" "sleeps unremember'd here," (p. 58) and their ambition ${ }^{9}$ for "destructive robbery, fire and sword" (p. 58) are also forgotten. Thus, "Smith not only defies the linear flow of time that demarcates past, present and future but also sees an organic unity

\footnotetext{
${ }^{8}$ Sert discusses that "what Smith is criticizing here is not science itself: it is the rational Enlightenment male scientist that studies, analyzes, rationalizes and theorizes on the physical world from a distance" (2018, p. 94). Although Sert criticizes the dominance of a denying male version of science, her view on Smith's use of details and the poet's interest in botany or geography as "Smith finds a feminine terrain that focuses on the local, the minute, the material, which does not require her to transcend or totalize but to closely observe and catalogue" (p. 95) in a way, puts Smith into the same league as "the rational Enlightenment male scientist" (2018, p. 94) the group from whom the poet distinguishes her attitude with "vague theories" $(2005$, p. 57) in "Beachy Head." Sert suggests that the poet "might have-voluntarily or involuntarilyinternalized the idea of reason's supremacy" (2018, p. 85) by referring to the influences of the Neoclassical poetry in Smith. However, in "Beachy Head," such influence is refuted with a deliberate Romantic attitude about the superiority of Nature.

${ }^{9}$ Smith uses the word 'ambition' in totally negative terms when compared to Burke's arguments on ambition and its influence on the creation of the Sublime in his A Philosophical Enquiry into the Origin of Our Ideas of the Sublime and Beautiful.
} 
of men, though centuries apart, still together on the same land" (Sert, 2018, p. 137). Then, a Roman commander lying under the soil of the island shares the same fate with the Dane, which means in spite of their fame and power they are levelled to the same position of "the savage native, who his acorn meal/ Shar'd with the herds, that ranged the pathless woods" (p. 58). In this respect, "her [Smith's] sublime is not found in an overwhelming grandeur but in the infinite within the finite" (Ruwe, 1999, p. 127). Thus, endless resources of Nature reshape the landscape (the ruins from early ages are only imprints) and dominate over the limited humankind. In a similar manner, the persona's words stand as a moral lesson for the "human crimes" (Smith, 2005, p. 58) since humanity cannot "Come and behold the nothingness of all/ For which you carry thro' the oppressed Earth,/ War, and its train of horrors," (p. 58)

But now a tiller of the soil dwells there,
And of the turret's loop'd and rafter'd halls
Has made an humbler homestead- Where he sees,
Instead of armed foemen, herds that graze
Along his yellow meadows; or his flocks
At evening from the upland driv'n to fold
In such a castellated mansion once
A stranger chose his home. (Smith, 2005, p. 58)

As Smith states in her footnote, "In this country there are several of the fortresses or castles built by Stephen of Blois (King of England, 1135-54) in his contention for the kingdom, with the daughter of the Henry the First, the empress Matilda. Some of these are now converted into farm houses" (2005, p. 60), the grandiose mansions converted into simple farmhouses visualise the hollowness of the "war and its train of horrors" (p. 58). According to Sert, "the destruction and death entailed by wars and politics is almost always replaced by the rejuvenating and prosperous nature and human toil" (2018, p. 137). The conversion from the grandiose to the simple through the changing place images can also suggest a different perception of history. The emphasis on the ruins and the shipwrecks towards the end of the poem signifies the change occurring on the subjective and topographical levels. In this respect, Morrison's discussion of history as "garbage" $(2015$, p. 57) can be applicable to the poem's concentration on these ruins specified in the poet's footnotes since "orderly and tidy linear progression crumbles when jettisoned scraps return to prowl through narrative sequence" (p. 57). However, as Morrison maintains, "the poignant impossibility of trying to recover the past lies at the heart of the plight of history, making us look back to a longed-for state we can never be in again" $(2015$, p. 57). Such yearning appears in the poem as a longing for childhood memories as it happens in a regular nineteenth century romantic poem. But the poem also offers a hopeful solution to alleviate the sorrows brought with history by means of ruins, fossils and wrecked ships as these images carry both the past residue of completeness and the present feeling of loss. Accordingly, in order to cope with the sense of hollowness, the poetic persona also returns to the stories of the dwellers of Beachy Head. The descriptions of a shepherd trying to keep his flock from the fields and a 
master carrying grain to the windmill soothe her remembrance of the man-centred history since those figures signify the possibility of reunification with Nature without disturbing it.

\section{... the tir'd hind}

Pass'd him at nightfall, wondering he should sit

On the hill top so late: they from the coast

Who sought bye paths with their clandestine load,

Saw with suspicious doubt, the lonely man

Cross on their way: but village maidens thought

His senses injur'd; and with pity say

That he, poor youth! must have been cross'd in love- (Smith, 2005, p. 61)

In the closing stanzas, the persona presents two hermit figures who are situated in the margin of the cultural space. The stranger residing in the ruins of a Roman battlement wanders in the woods in order to suppress his love for "Amanda" (Smith, 2005, p. 64) as it is indicated in the last stanza of his songs. However, his melancholy paradoxically does not lead to any painful experience with the healing power of Nature. In other words, his loitering mood only finds a stable ground in the continuity of Nature. Nevertheless, as the above lines suggest, he is distanced from the social or cultural space, which creates wonder, suspicion, or pity in the neighbourhood. That is to say, every reaction consolidates his stance on the periphery, and he cannot be registered in the order of the dominant discourse. Thus, he becomes a nameless person as being only a 'stranger' and a rootless figure without any known personal history. Although he does not have any contact with the people around him to befriend him, his songs have a therapeutic influence and function as a voice for him to reflect the subjective yearnings and sufferings,

\section{And then in silence, gliding like a ghost}

He vanish'd! Lost among the deepening gloom.

But near one ancient tree, whose wreathed roots

Form'd a rude couch, love-songs and scatter'd rhymes,

Unfinish'd sentences, or half erased,

And rhapsodies like this, were sometimes found (Smith, 2005, p. 62)

The stranger experiences a Wordsworthian leap from the natural space into the visionary one. He identifies his love for Amanda with the natural beauties that pave the way for a dreamy space. Then, his endurance in the linearity changes into a blissful temporality in which he "May haply build his cane-constructed bower/ Beneath the bread-fruit, or aspiring palm,/ With long green foliage rippling in the gale./ Oh! let him cherish his ideal bliss" (p. 64).

Another hermit figure is poeticised as a man living in the caverns of the Beachy Head. Charlotte Smith recounts the source for the image of this lonely man helping the shipwrecked in her footnote as follows, 
In a cavern almost immediately under the cliff called Beachy Head, there lived, as the people of the country believed, a man of the name of Darby, who for many years had no other abode than this cave, and subsisted almost entirely on shell-fish. he had often administered assistance to ship-wrecked mariners; but venturing into the sea on this charitable mission during a violent equinoctial storm, he himself perished. As it is above thirty years since I heard this tradition of Parson Darby (for so I think he was called): it may now perhaps be forgotten. (Smith, 2005, p. 65)

"The hermit of the rocks," (Smith, 2005, p. 65) relates his sense of time with the circularity of Nature. In this respect, his organic relation with Nature is reflected in such acts as reading weather through the "clouds of heaven" or "changing colours of the sea" (p. 65) and understanding seasonal changes through the migrant birds, fog, or rise in the sea level. He deliberately chooses to live on the periphery since the deeds of man situated in the cultural ground inflicts only sorrow and anger on him due to his immense love for the human beings and other animate/ inanimate beings as stated in the lines ". . . for his heart/ Was feelingly alive to all that breath'd;/ And outraged as he was, in sanguine youth,/ By human crimes, he still acutely felt/ For human misery" (p. 65). Besides emblematising the notion of charity (a popular issue in the nineteenth century), the hermit and his tragic end also reflect the persona's own trouble with the cultural space and her prospect for annulling linearity and spatiality as poeticised in the lines "His spirit, from its earthly bondage freed,/ Had to some better region fled forever" (p. 66).

\section{CONCLUSION}

"Beachy Head" glorifies the significance of Nature. Culture, on the contrary, stands as a source of both personal and social problems in the poem. In other words, the poem discusses that while the first one triggers the sense of immortality and change, the latter one tries to impose its limited space on human beings. The study demonstrates this essential incongruity between Nature and culture through certain elements such as shepherd or farmer, fossils, ruins and hermits. Through her narration, the observing eye implicates her distance and way of thinking based on culture. In this respect, the narrator's reactions towards time, historical events and landscape within the specific place of Beachy Head reflects the degree of the impeding cultural heritage for both the persona and the ones she narrates their stories.

Although the persona observes her surrounding from a particular spot, in some cases, her depictions leap from the empirical realm to the visionary one, so her reactions signify the desire for going beyond the cultural space towards the natural one. However, the persona's sense of the Sublime and her immediate turns to the physical descriptions of sailors or landscape also reflect her attitude of grasping the actual without denying the sublime experience. Thus, the persona's passivity in the position of an observer does not hinder her from indicating her own emotions. She actively proposes her criticism about culture, city life and the historical residue. 
Thus, "Beachy Head" becomes the juxtaposition of contrasting ideas and emotions throughout different vantage points and stories conveyed through the long narrative style of the poem. Consequently, the poem provides a space for selfconfrontation, since in "Beachy Head," the persona demonstrates both what the hermit achieves through the serenity of Nature and what she loses in her presence in the cultural space.

\section{REFERENCES}

Bernstein, S. (2007). "Nature seem'd to lose her course:" Crisis historiography and historiographic crisis in Charlotte Smiths the Emigrants. L. Felber (Ed.), In Clio's Daughters: British Women Making History 1790-1899. (pp. 29-42). New Jersey: U of Delaware P.

Bode, C. (2008). The subject of Beachy Head. J. Labbe (Ed.), In Charlotte Smith in British Romanticism. (pp. 57-69). London: Pickering\& Chatto.

Burke, E. (1823). A philosophical enquiry into the origin of our ideas of the Sublime and Beautiful with an introductory discourse concerning taste and several other additions. London: Thomas M'Lean, Haymarket.

Cognevich, C. (2020). Inside voice: Charlotte Smith, Silence, and the sonnet of insensibility. Essays in Romanticism, 27 (1), 1-22.

Coleridge, S. T. (1847). Aids to Reflection. New York: Stanford\& Swords.

Curran, S. (1994). Charlotte Smith and British Romanticism. South Central Review, 11 (2), 66-78.

Fletcher, L. (2001). Charlotte Smith: A critical biography. New York: Palgrave Macmillan.

Garnai, A. (2009). Revolutionary imaginings in the 1790s: Charlotte Smith, Mary Robinson, Elizabeth Inchbald. Hampshire and New York: Palgrave Macmillan.

Girten, K. M. (2013). Charlotte Smith's tactile poetics. The Eighteenth Century, 54 (2), Special Issue: Sensational Subjects, 215-230.

Goodman, K. (2014). Conjectures on Beachy Head: Charlotte Smith's geological poetics and the grounds of the present. ELH, 81 (3), 983-1006.

Holt, K. M. (2014). Charlotte Smith's Beachy Head: Science and the dual affliction of minute sympathy. ABO: Interactive Journal for Women in the Arts, 1640-1830, 4 (1), 1-14.

Labbe, J. M. (2011). Writing Romanticism: Charlotte Smith and William Wordsworth, 1784-1807. Hampshire and New York: Palgrave Macmillan. 
Morrison, S. (2015). The Literature of Waste: Material Ecopoetics and Ethical Matter. New York: Palgrave Macmillan.

Paterson, A. (2019). Tracing the Earth: Narratives of personal and geological history in Charlotte Smith's Beachy Head. Romanticism, 25 (1), 22-31.

Pratt, K. (2001). Charlotte Smith's melancholia on the page and stage. Studies in English Literature, 1500-1900, 41 (3), 563-581.

Roberts, B. (2019). Charlotte Smith and the sonnet: Form, place and tradition in the late eighteenth century. Liverpool: Liverpool UP.

Ruwe, D. (1999). Charlotte Smith's sublime: Feminine poetics, botany, and Beachy Head. Essays in Romanticism, 7 (1), 117-132.

Sert, G. (2018). Charlotte Turner Smith: A harbinger of romantic poetry? (Unpublished PhD Dissertation). Middle East Technical University, The Graduate School of Social Sciences, Ankara.

Smith, C. (2005). Beachy Head. J. Reidhead (Ed.), In The Norton Anthology: English Literature, Volume 2. (pp. 47-66). New York and London: Norton.

Tayebi, K. (2004). Undermining the eighteenth-century pastoral: Rewriting the poet's relationship to nature in Charlotte Smith's poetry. European Romantic Review, 15 (1), 131-150.

Zimmerman, S. (1991). Charlotte Smith's letters and the practice of selfpresentation. The Princeton University Library Chronicle, 53 (1), 50-77. 